\title{
The Effect of an Education-Themed Movie on the Academic Motivation of Teacher Candidates and Their Attitude towards Teaching Profession
}

\author{
Hakkı Kontaş \\ Correspondence: Hakkı Kontaş, Faculty of Education, Adıyaman University, Adıyaman, 02040, Turkey
}

Received: March 7, 2016 Accepted: March 16, $2016 \quad$ Online Published: March 22, 2016

doi:10.11114/jets.v4i6.1483 URL: http://dx.doi.org/10.11114/jets.v4i6.1483

\begin{abstract}
The purpose of this study is to analyze the effect of an education-themed movie on the academic motivation of teacher candidates and their attitude towards teaching profession. The study was carried out in the fall term in 2014-2015 academic year with the participation of 89 teacher candidates (53 in experimental group and 36 for control group). In the study, quasi-experimental design with pre-test/post-test control group was used. "Academic Motivation Scale" and "Attitude Scale towards Teaching Profession" were used for data collection. Dependent group t-test and independent group t-test were used in analyses. Findings of the research indicated that the education-themed movie has a significant effect on intrinsic motivation and extrinsic motivation external regulation dimensions of academic motivation scale and love, value and harmony dimensions regarding teaching profession on the experiment group.
\end{abstract}

Keywords: education-themed movie, academic motivation, attitude towards teaching profession, teacher candidates

\section{Introduction}

The quality and features of education are directly associated with the professional and personal properties of teachers. Various factors in the system, as well as the qualifications of teachers, are of critical importance during the educational activities at schools (Erdem \& Gözel, 2014). Student's interest in the subject and his desire to learn it, which are two of the most important components for and placed in the core of the learning process, are crucial for the educational activities to attain their goals. Providing this is closely related to the concept of motivation. As Aktürk (2012) puts it, in order for educational activities to reach the expected objectives, the teachers take on some significant tasks, such as employing the components of education appropriately for the purpose, choosing the relevant methods and motivating the students for learning. Moreover, Ayık and Ataş (2014) indicate the importance of teaching profession in terms of humanistic sensitivity. The individuals choosing that profession are expected to have an adequate level of sensitivity, together with a high and positive attitude and awareness towards their profession. This kind of sensitivity is related to personal characteristics of people and significantly affects their psychological health. However, Özgüngör and Kapıkıran (2008) suggest that the teacher candidates do not choose their profession willingly and that their negative attitudes towards teaching affect their motivation adversely, and that, on either occasion, those students undervalue the profession of teaching. Because, taking into consideration that teaching both affects and is affected by social environment, individuals with high or low self-esteem level are expected to reflect that condition to their teaching duties and responsibilities as well (Abbasoğlu, 2011). For this reason, in order to attain the desired objectives in educational activities, the teachers should be sufficiently motivated in terms of their professional and personal properties, their mood and attitude towards teaching profession and should be at a high level, and that motivation should be as stable as possible (Erdem \& Gözel, 2014). As İlter states (2013), it is a prerequisite for the teachers to guide the students in the facilitation of learning, to provide social and mental interaction in learning environments and to motivate them constantly for academic success, with the aim of integrating the students actively into the learning process. In brief, an individual priory needs to have sufficient motivation so as to achieve professional satisfaction and pleasure. Erdem and Gözel (2014), assert that highly-motivated teachers are a need for individuals to be able to sort out their problems, accommodate themselves with the values of society and become productive and helpful for the society and country; because highly-motivated teachers will work more ardently at work and will have a positive attitude towards teaching profession, thus engaging better in teaching, which will eventually increase the quality of education. That is why, conscious motivation skills are essential in order to increase the efficiency of teachers and make it sustainable. The way to achieve that is by being aware of the factors increasing and decreasing motivation in teachers and, taking those factors into consideration, providing teachers with educational environments in which they can work happily, peacefully 
and eagerly. Gökay and Özdemir (2010) and İman (2014) put forth that some of the other factors important and influential in practicing the teaching profession are the teachers' attitude towards their profession, whether they perform it willingly, and whether they have the motivation for it, as well as having affection for children.

The purpose of this study is to analyze the effect of an education-themed movie on the academic motivation of teacher candidates and their attitude towards teaching profession during their pre-service training. To this end, the answers to following questions are to be sought:

a) Is there a significant difference between the academic motivation and attitude towards profession of teaching mean scores of experiment and control groups after the film?

b) Is there a significant difference between the academic motivation and attitude towards profession of teaching mean scores of the control group before and after the film?

c) Is there a significant difference between the academic motivation and attitude towards profession of teaching mean scores of the experiment group before and after the film?

In the information society of our day, the importance of teaching profession in terms of development of countries has largely influenced teacher training programs as well. Because the developmental level of a country is directly related to the status of teaching profession in it; that is, development of a country depends on training its teachers well (Bek, 2007). Indeed, there is a strong relationship between the social status and prestige of a profession and the quality of the people performing that profession. More people are oriented towards professions with a high status and the most successful ones among them are chosen. In addition, people performing professions with a high status usually have higher motivation and less anxiety towards their jobs (Özoğlu, Gür, \& Altunoğlu, 2013).

Since it has important influences on classroom behaviors of teachers, many of teacher training programs aim at improving their students' belief about education (Çakıroğlu \& Işıksal, 2009). Improving the academic motivation of teacher candidates and their attitudes towards teaching profession will, thus, contribute to their success and devotion in professional life, which may, in turn, be considered as a step to increase the quality of teaching profession as well as a means to increase the student success. The attitude of teachers towards their profession reflects their conception of it, that is their "teaching profession perception", in that it is one of the strongest determinants of their professional behaviors. Thus, learning experiences of teachers in their student periods form a basis for their perception of profession (Can, 1987).

\subsection{Literature Review}

\subsubsection{Motivation}

This word, which is derived from "motif" in old English and French, is defined as an incentive which drives someone for a specific purpose (Erdem \& Gözel, 2014), the decisiveness, liveliness and continuousness in someone's behavior created by internal and external influences to guarantee some specific behavior (Barutçugil, 2004, s. 372). Many studies about motivation have been carried out including various student and teacher groups, both in Turkey (Acat \&Yenilmez, 2004; Ada, Akan, Ayık et al., 2013; Akbaba, 2006; Aktürk, 2012; Argon, İsmetoğlu \& İşer, 2014; Ayık \& Ataş, 2014; Bozanoğlu, 2004; Dereli \& Acat, 2010; Erdem \& Gözel, 2014; Eymur \& Geban, 2011; Gök, 2009; Gökay \& Özdemir, 2010; İman, 2014; Obuz, 2011; Özgüngör \& Kapıkıran, 2008; Yavuz \& Karadeniz, 2009; Yılmaz \& Aslan, 2013) and abroad (Akpan \& Umobong, 2013; Ames \& Archer, 1988; Dörnyei, 2001; Gardner, 1985; Greene, Miler, Crawson et al., 2004; Jonett, 2009; LeJeune, 2014; Nelson, 2011; Robertson, 2010; Ryan \& Deci, 2000; Settlemyer, 2010; Wagner, 2006; Wall, 2013; Weiner, 1990; Zou, 2000).

When those studies are examined, it can be seen that many different ideas and descriptions as to the origin and definition of motivation have been suggested both in Turkey and abroad. Pintrich and Schunk (1996:4) define motivation as something that makes us start an action, continue to do it and helps us to finish it; or the set of aim-oriented processes initiated by updated or "loaded" needs such as impulses, wishes, ambitions, tendencies, aspirations, effort and desires, which drive the individual to a direction either consciously or unconsciously.

Motivation is a factor effective in manifesting and triggering an individual's behaviors. Gömleksiz and Serhatlığlu (2013) believe that motivation is a truly important factor affecting the behaviors and attitudes of students through all stages of education. It can be observed that in classes, some students are keen on the subject told during the lesson or eager to solve a given problem whereas some others are unwilling and intimidated about solving the problem they were asked. One of the reasons of this condition of students is existing or non-existing motivation (Küçükosmanoğlu, 2015). For this reason, the teachers should be aware of the importance of motivation in class (Karataş, 2011). Achieving the goals of teaching activities through the learning process is only possible if the student is interested in the subject and wants to learn it. One of the most important factors that arouses interest and curiosity in students and helps them become constructive, creative and productive individuals by pushing them to active involvement in the lesson is the 
motivation that teachers will provide for students. As Walker (1982) puts it, the teacher is the most important determinant of student motivation in learning. İlter (2013) asserts that teachers have to provide students with learning environments including rich experiences and stimuli aimed at both intrinsic and extrinsic motivation which, in turn, will lead them to be actively involved in the lesson. Students at education faculties, especially, need a high motivation in order to become qualified teachers in the future (Uyulgan \& Akkuzu, 2013). High motivation ensures an increased performance in professional life. The motivation of teachers and teacher candidates about their professions is also significant in that it reflects their feelings and ideas regarding their job. Teachers are at the core of educational systems with regard to their significance in shaping and transforming the societies. The duties and responsibilities of teachers have evolved from being a transmitter of information, the only source of it and an authority in the class into being an advisor for students to reach information and use it effectively, a pioneer for social transformation and a guide for students. As a result, the knowledge and qualifications that the teachers acquire during pre-service education becomes more important (Altınkurt, Yılmaz, \& Erol, 2014).

One of the most remarkable and comprehensive studies about motivation is the one by Ryan and Deci. According to Ryan and Deci (2000) people differ not only at their levels of motivation but also at their types of motivation. In other words, people are different from each other in respect to the level of motivation which shows how much motivation they have, as well as disposition to motivation types which show the kind of motivation they possess.

\subsubsection{Academic Motivation}

Academic motivation is an important factor on academic success and performance through education. (Linnenbrink \& Pintrich, 2002). Ryan and Deci (2000), state that academic motivation is associated with various outputs such as curiosity, learning and performance. It can be seen that many definitions as to academic motivation have emerged in the literature. According to those studies academic motivation is defined as the measurement of a student's desire for achievement in basic content (Olsen, 2015); a student's will to enter a university or school and resolution to complete the academic goals (Kaisershot, 2006); the process of beginning and maintaining goal-oriented actions about education (Montgomery, 1999); a student's willingness and readiness towards lessons and learning activities, the degree of allocating all of his attention and effort in various actions or an individual's love for and desire to the activities related to learning (Cave, 2003); a process in which goal-oriented actions are taken and continued (Schunk, Pintrich, \& Meece, 2008). Based on those definitions, while motivation is the unaware/involuntary action of an individual without realizing its goal, academic motivation involves the awareness of the individual as to the goals and destination of his actions. (Uyulgan \& Akkuzu, 2013). İman (2014) puts forth that the motivation/academic motivation level of teachers affect their "attitude towards the profession of teaching" and carrying out their work to a great extent. Because, when we take into consideration the fact that profession of teaching affects and is affected by the social environment, an individual with a high or low self-esteem is expected to reflect this trait to the duties and responsibilities of teaching as well (Abbasoğlu, 2011).

\subsubsection{Attitude towards Teaching Profession}

Attitude towards the profession is an indicator of professional behavior and reflects the professional perception of teachers. The experiences and education that teacher candidates gather during their training at educational institutions form a basis for their professional lives; that is why, the educational environment of teacher candidates and their experiences, the methods-techniques and instruments there should be arranged in a way so as to create positive attitudes towards the profession (Abbasoğlu, 2011). After examining the studies on both academic motivation and attitude towards teaching profession, factors affecting the attitude and motivation are listed as above. Based on that information, it can be concluded that teachers/instructors should employ the appropriate strategies, techniques, methods and instruments in the class for extrinsic and intrinsic motivations to be influential on the individual. Among those instruments, mass media and training technologies have an important place, as mass media is considerably influential upon individuals in information age. TV, computer, internet, cinema and films served via them surround nearly all parts of our daily lives. Those audio-visual media brought about by technology have become effective in the field of education as well as other fields. Application of those media can accurately and effectively help progress in education. Cinema is still one of the most influential among them by means of the movies. Birkök (2008) states that movies serve as a means of socialization and education, that they will become an indispensable tool of education for education models and strategies in the future and are a perfect means for explaining the human influence in every circumstance. Moreover, in his study Birkök (2008) emphasizes two important features of movies with regard to socialization. The first one is the ability of movies to convey a great amount of information via use of action, sound and image altogether; he clarifies that it is impossible to perceive abstract meanings such as sound and feeling and the only way to pass on those phenomena effectively is through movies. Secondly, they can convey the real meanings of social phenomena and ideas and also feelings and have the characteristic of reviving the abstract information in course books with all of their elements and transforming it into real life. 
Movies, comprising a lot of information and messages in themselves, play an important role in helping people decide how to behave or what to choose and in bringing identity and value to them. One of the leading aims of movies is not only providing visuality for individuals, but also providing some values, ideas and information; moreover, the fact that movies are multi-colored and employ different sound effects ensures them to be watched easily and with interest (Altıntaş, 2008). The use of such visual and audial media facilitates the students to learn while entertaining them, to focus on the subject as desired and to get in touch with the problems of real life (Kapucu, 2014). Movies associate abstract concepts with the lives of individuals as concrete concepts, which fulfill the educational function of movies (Can, 1987). Indeed Birkök (2008) regards the movie not only as an enricher for teaching instruments, but also a component of education in itself. Because its appearance on the object shaped in one's mind contributes both to the publication of a belief or idea and to the learning ability of the individual (Altıntaş, 2008). As Birkök (2008) asserts, movies can revive abstract information as a whole with all of related elements or transform it into real life; thus they provide an analysis and interpretation to the complexity of our lives and forming a both individualistic and social perspective, eliminate any prejudices and help different generations develop an understanding towards each other.

\section{Method}

In this part, the research design, study group, data collection tools and the analysis of data are explained.

\subsection{Research Design}

The quasi-experimental pre-test/post-test control group model was used in this study. There are two groups formed through unbiased allocation. One is used as experiment group and the other as control group. Measurements are taken from both groups before and after the experiment (Büyüköztürk, 2004; Karasar, 2005). The symbolic appearance of the model is as follows:

Table 1. Pre-test/Post-test Control Group Model

\begin{tabular}{llll}
\hline $\mathrm{G}_{1}$ & $\mathrm{O}_{1.1}$ & $\mathrm{X}$ & $\mathrm{O}_{1.2}$ \\
$\mathrm{G}_{2}$ & $\mathrm{O}_{2.1}$ & & $\mathrm{O}_{2.2}$ \\
\hline
\end{tabular}

\subsection{Participants}

The study group of this research consists of 120 freshman teacher candidates studying at primary school teaching in the Faculty of Education of Adiyaman University in the fall semester of 2014-2015 academic year. For the reasons such as missing either pretest of posttest, or discontinuing the film, 31 participants, 7 from experiment and 24 from the control group were excluded from the study. 53 ( 46 female, 7 male) of the candidates were enrolled in experiment group and 36 (30 female, 6 male) in control group. The participants ranged 18-19 years in age.

The results of the t-tests which were conducted to find out whether there was any difference in AMS and ASTP scores of the control and experiment groups.

Table 2. Comparison of AMS Scores of Experiment and Control Groups before the Film

\begin{tabular}{|c|c|c|c|c|c|c|}
\hline Sub-scales & Groups & $\mathrm{n}$ & $X$ & $S d$ & $t$ & $p$ \\
\hline \multirow{2}{*}{ Intrinsic Motivation } & Experiment & 53 & 38.86 & 5.99 & \multirow{2}{*}{1.789} & \multirow{2}{*}{.070} \\
\hline & Control & 36 & 34.38 & 6.99 & & \\
\hline \multirow{2}{*}{ Amotivation } & Experiment & 53 & 12.25 & 2.47 & \multirow{2}{*}{.651} & \multirow{2}{*}{.517} \\
\hline & Control & 36 & 11.86 & 2.63 & & \\
\hline \multirow{2}{*}{ Introjected Regulation and Accomplishment } & Experiment & 53 & 15.95 & 5.08 & \multirow{2}{*}{1.268} & \multirow{2}{*}{.208} \\
\hline & Control & 36 & 14.62 & 4.53 & & \\
\hline \multirow{2}{*}{ Extrinsic Motivation- External Regulation } & Experiment & 53 & 12.25 & 2.47 & \multirow{2}{*}{651} & \multirow{2}{*}{.517} \\
\hline & Control & 36 & 11.89 & 2.63 & & \\
\hline \multirow{2}{*}{ Extrinsic Motivation- Identified Regulation } & Experiment & 53 & 17.47 & 2.63 & \multirow{2}{*}{.287} & \multirow{2}{*}{.775} \\
\hline & Control & 36 & 17.31 & 2.76 & & \\
\hline
\end{tabular}

According to the data in Table 2, though there was a difference between the AMS mean scores of experiment and control groups before the film, it was detected to be insignificant ( $p>.05)$. This result showed that experiment and control groups matched in terms of AMS mean scores.

Table 3. T-test Results of ASTP Scores of Experiment and Control Groups before the Film

\begin{tabular}{lllllll}
\hline Sub-scales & Groups & $\mathrm{n}$ & $\overline{\boldsymbol{X}}$ & $S d$ & $t$ & $p$ \\
\hline \multirow{2}{*}{ Love } & Experiment & 53 & 90.30 & 15.30 & \multirow{2}{*}{.682} & \multirow{2}{*}{.497} \\
& Control & 36 & 87.89 & 17.84 & & \\
Value & Experiment & 53 & 37.45 & 3.45 & \multirow{2}{*}{-1.956} & .054 \\
\multirow{2}{*}{ Harmony } & Control & 36 & 38.64 & 1.38 & & \\
& Experiment & 53 & 19.40 & 4.09 & \multirow{2}{*}{-1.540} & .127
\end{tabular}

According to the data in Table 3, though there was a difference between the ASTP mean scores of experiment and 
control groups before the film, it was detected to be insignificant ( $p>.05)$. This result showed that experiment and control groups matched in terms of ASTP mean scores.

\subsection{Instruments}

\subsubsection{Attitude Scale towards Teaching Profession (ASTP)}

In order to assess the attitudes of teacher candidates towards teaching profession, ASTP developed by Çetin (2006) was used. There are 35 items, of which 15 are negative and 20 are positive, in the five-point likert-type scale. In the scale, the positive statements are scored as " $5,4,3,2,1$ " ranging from "strongly agree" to "strongly disagree", whereas the negative statements are scored vice versa as " $1,2,3,4,5$ " ranging from "strongly agree" to "strongly disagree". The minimum score is 35 and maximum score is 175; scores above 92-119 interval are considered positive and those below 92-119 as negative, whereas scores between 92-119 are considered neutral attitude. The scale consisting of three dimensions named love, value and harmony is scored both as total score and also separately for each of the sub-dimensions. Cronbach Alpha reliability coefficient is .95 for the total of the scale, .95 for love dimension, .81 for value dimension and .76 for harmony dimension. The Cronbach Alpha value calculated for this study varies between .89 and .95. Detailed information about both scales is given in Table 3.

\subsubsection{Academic Motivation Scale}

Academic Motivation Scale (AMS) was developed by Vallerand et al. (1992) and was adapted into Turkish by Karagüven (2012). The scale consists of 28 items. The original scale was made up of seven sub-scales and at the end of adaptation it was indicated to have five factors. The first factor "intrinsic motivation" comprises nine items, the second factor "amotivation" four items, the third factor "introjected regulation-accomplishment" five items, the fourth factor "extrinsic motivation-external regulation" three items and the fifth factor "extrinsic motivation-identified regulation" four items. There are seven degrees that can be marked ranging from 1 (does not correspond at all) to 7 (corresponds exactly) for each statement. However, in this study the scores were given in a range of 1("does not correspond at all") to 5 (corresponds exactly). There are no reverse-scored items in the scale. Cronbach Alpha value of the scale for this study varies between .59-.65. This value demonstrates the reliability of this scale for the study. Detailed information on both scales is given in Table 4.

Table 4. Reliability Table for Academic Motivation Scale and Attitude Scale towards Teaching Profession

\begin{tabular}{lllllllll}
\hline \multicolumn{3}{c}{ Pretest } & \multicolumn{1}{c}{ Posttest } \\
& Control & \multicolumn{3}{c}{ Experiment } & \multicolumn{2}{c}{ Control } & \multicolumn{2}{c}{ Experiment } \\
& AMS & ASTP & AMS & ASTP & AMS & ASTP & AMS & ASTP \\
\hline Cronbach alpha & .805 & .935 & .830 & .902 & .858 & .953 & .820 & .896 \\
\hline
\end{tabular}

2.4 Analysis of Data

"t-test for independent samples" was used in order to assess whether there was a significant difference between pretest and posttest groups in the academic motivation and attitudes towards teaching profession of study group; and "dependent t-test was used in order to assess whether there was a significant difference for the groups in themselves.

\subsection{Experimental Procedure}

This study was conducted within the scope of Introduction to the Science of Education course of the teacher candidates. Firstly, the assessment instruments were applied with the experiment and control group students. One week later, the participants in the experiment group were asked to watch "Taare Zameen Par", a 2007-Indian movie produced and directed by Aamir Khan, whereas the lesson of participants in the control group was not intervened. The film, which is 165 minutes long, is about a dyslexic child having an undiscovered extraordinary skill in painting who is isolated from the school and educational system until a special education teacher discovers his difficulty and leads him through the path to success. The film illustrates the extent to which the motivation and determined struggle of a teacher could change the life of a student. The study ended with applying the same assessment tools again on experiment and control groups.

\section{Findings}

A comparison of academic motivation and attitude towards teaching profession mean scores of experiment and control groups before the film was given in Tables 2 and 3. Table 5 and Table 6 show the results of AMS and ASTP scores of the groups following the application. 
Table 5. T-test Results of AMS Mean Scores of Experiment and Control Groups after the Film

\begin{tabular}{|c|c|c|c|c|c|c|}
\hline Sub-scales & Groups & $\mathrm{n}$ & $\overline{\bar{X}}$ & $S d$ & $t$ & $p$ \\
\hline \multirow[b]{2}{*}{ Intrinsic Motivation } & Experiment & 53 & 38.81 & 5.05 & \multirow{2}{*}{2.557} & \multirow[b]{2}{*}{$.012^{*}$} \\
\hline & Control & 36 & 35.67 & 6.53 & & \\
\hline \multirow{2}{*}{ Amotivation } & Experiment & 53 & 4.92 & 2.45 & \multirow{2}{*}{-1.051} & \multirow{2}{*}{.296} \\
\hline & Control & 36 & 5.53 & 2.94 & & \\
\hline \multirow{2}{*}{ Introjected Regulation and Accomplishment } & Experiment & 53 & 15.70 & 4.80 & \multirow{2}{*}{-.099} & \multirow{2}{*}{.921} \\
\hline & Control & 36 & 15.81 & 5.33 & & \\
\hline \multirow{2}{*}{ Extrinsic Motivation- External Regulation } & Experiment & 53 & 10.57 & 2.93 & \multirow{2}{*}{-2.983} & \multirow{2}{*}{$.004^{*}$} \\
\hline & Control & 36 & 12.36 & 2.55 & & \\
\hline \multirow{2}{*}{ Extrinsic Motivation- Identified Regulation } & Experiment & 53 & 17.38 & 2.36 & \multirow{2}{*}{.132} & \multirow{2}{*}{.895} \\
\hline & Control & 36 & 17.31 & 2.72 & & \\
\hline
\end{tabular}

When the t-test results in Table 5 were analyzed, it was seen AMS "intrinsic motivation" mean scores of both experiment and control groups increased significantly, and "extrinsic motivation-identified regulation" sub-scale mean scores decreased significantly after the film in favor of the experiment group $(\mathrm{t}=-2.983$, $\mathrm{p}<.05)$. There was no significant difference in other sub-scales. Those results suggest that education-themed movie had a significant effect on increasing the intrinsic motivation scores of the experiment group and decreasing the extrinsic motivation-external regulation scores, while it did not create a significant effect on other sub-scales. ASTP mean scores of experiment and control groups after the film are compared in Table 6.

Table 6. T-test Results of ASTP Mean Scores of Experiment and Control Groups after the Film

\begin{tabular}{lllllll}
\hline Sub-scales & Groups & $\mathrm{n}$ & $\overline{\boldsymbol{X}}$ & $S d$ & $t$ & $p$ \\
\hline \multirow{2}{*}{ Love } & Experiment & 53 & 99.89 & 10.87 & \multirow{2}{*}{3.330} & $.001^{*}$ \\
& Control & 36 & 89.17 & 19.41 & & \\
Value & Experiment & 53 & 38.64 & 1.89 & .271 & .787 \\
& Control & 36 & 38.53 & 2.02 & & \\
\multirow{2}{*}{ Harmony } & Experiment & 53 & 21.45 & 3.12 & \multirow{2}{*}{1.476} & .144 \\
& Control & 36 & 20.33 & 4.03 & & \\
\hline
\end{tabular}

When mean scores of experiment and control groups after the film were compared based on the t-test result in Table 6 , the mean scores in "love" sub-scale of the experiment group $(\bar{X}=99.89)$ was found to be significantly higher than those of the control group $(\bar{X}=89.17)(\mathrm{t}=3.330, \mathrm{p}<.05)$. There was no significant difference between mean scores of experiment and control groups in other sub-scales. According to this finding, it can be said that the education-themed movie was effective in increasing the ASTP "love" sub-scale scores; however, it had no significant effect on other sub-scales. AMS and ASTP pre-test and post-test mean scores in control group are given in Tables 7 and 8.

Table 7. Comparison of AMS Pre-Test and Post-Test Scores in the Control Group

\begin{tabular}{|c|c|c|c|c|c|c|}
\hline Sub-scales & & $\mathrm{n}$ & $\bar{X}$ & $S d$ & $t$ & $p$ \\
\hline \multirow{2}{*}{ Intrinsic Motivation } & Pre-test & 36 & 34.39 & 6.99 & \multirow{2}{*}{-1.991} & \multirow{2}{*}{.054} \\
\hline & Post-test & 36 & 35.67 & 6.53 & & \\
\hline \multirow{2}{*}{ Amotivation } & Pre-test & 36 & 5.81 & 3.36 & \multirow{2}{*}{.781} & \multirow{2}{*}{.440} \\
\hline & Post-test & 36 & 5.53 & 2.94 & & \\
\hline \multirow{2}{*}{ Introjected Regulation and Accomplishment } & Pre-test & 36 & 14.61 & 4.53 & \multirow{2}{*}{-1.973} & \multirow{2}{*}{.056} \\
\hline & Post-test & 36 & 15.81 & 5.33 & & \\
\hline \multirow{2}{*}{ Extrinsic Motivation- External Regulation } & Pre-test & 36 & 11.89 & 2.63 & \multirow{2}{*}{-1.373} & \multirow{2}{*}{.178} \\
\hline & Post-test & 36 & 12.36 & 2.55 & & \\
\hline \multirow{2}{*}{ Extrinsic Motivation- Identified Regulation } & Pre-test & 36 & 17.31 & 2.75 & \multirow{2}{*}{.000} & \multirow{2}{*}{1.000} \\
\hline & Post-test & 36 & 17.31 & 2.72 & & \\
\hline
\end{tabular}

Based on the data in Table 7, it was seen that there was no significant difference between AMS sub-scales pre-test mean scores and post-test mean scores in the control group ( $\mathrm{p}>.05)$. It is feasible to say that AMS mean scores of the control group are similar for the pre-test and post-test.

Table 8. T-test Results of ASTP Pre-Test and Post-Test Mean Scores of the Control Group

\begin{tabular}{lllllll}
\hline Sub-scales & & $\mathrm{n}$ & $\bar{X}$ & $S$ & $t$ & $p$ \\
\hline \multirow{2}{*}{ Love } & Pre-test & 36 & 87.89 & 17.84 & \multirow{2}{*}{1.081} & .287 \\
& Post-test & 36 & 89.17 & 19.41 & & \\
\multirow{2}{*}{ Value } & Pre-test & 36 & 38.64 & 1.38 & .466 & .644 \\
\multirow{2}{*}{ Harmony } & Post-test & 36 & 38.53 & 2.02 & & \\
& Pre-test & 36 & 20.64 & 3.14 & .692 & .493 \\
& Post-test & 36 & 20.33 & 4.03 & & \\
\hline
\end{tabular}

According to the data in Table 8, it can be stated that there is no significant difference between ASTP pre-test and post-test mean scores of the control group and that the scores of the control group before and after the film are similar (p>.05). The AMS and ASTP pre-test and post-test mean scores of the experiment group are given in Table 9 and Table 10. 
Table 9. T-test Results of AMS Pre-Test and Post-Test Scores of the Experiment Group

\begin{tabular}{|c|c|c|c|c|c|c|}
\hline Subscales & & $\mathrm{n}$ & $\bar{X}$ & $S d$ & $t$ & $p$ \\
\hline \multirow{2}{*}{ Intrinsic Motivation } & Pre-test & 53 & 36.87 & 5.99 & \multirow{2}{*}{-3.832} & \multirow{2}{*}{$.000 *$} \\
\hline & Post-test & 53 & 38.81 & 5.05 & & \\
\hline \multirow{2}{*}{ Amotivation } & Pre-test & 53 & 5.32 & 2.52 & \multirow{2}{*}{1.080} & \multirow{2}{*}{.285} \\
\hline & Post-test & 53 & 4.92 & 2.45 & & \\
\hline \multirow{2}{*}{ Introjected Regulation and Accomplishment } & Pre-test & 53 & 15.94 & 5.08 & \multirow{2}{*}{.459} & \multirow{2}{*}{.648} \\
\hline & Post-test & 53 & 15.70 & 4.80 & & \\
\hline \multirow{2}{*}{ Extrinsic Motivation- External Regulation } & Pre-test & 53 & 12.25 & 2.47 & \multirow{2}{*}{4.444} & \multirow{2}{*}{$.000 *$} \\
\hline & Post-test & 53 & 10.57 & 2.93 & & \\
\hline \multirow{2}{*}{ Extrinsic Motivation- Identified Regulation } & Pre-test & 53 & 17.47 & 2.63 & \multirow{2}{*}{.256} & \multirow{2}{*}{.799} \\
\hline & Post-test & 53 & 17.38 & 2.36 & & \\
\hline
\end{tabular}

Based on the data in Table 9, it can be seen that AMS "intrinsic motivation" post-test mean scores in the experiment group $(\bar{X}=38.81)$ are significantly higher than pre-test mean scores $(\bar{X}=36.87)(\mathrm{t}=-3.382, \mathrm{p}<.05)$. "Extrinsic motivation-external regulation" post-test mean scores in the experiment group $(\bar{X}=10.57)$ were found to be significantly lower than pre-test mean scores $(\bar{X}=12.25)(\mathrm{t}=4.444, \mathrm{p}<.05)$; there was no significant difference in other sub-scales. This finding demonstrates that education-themed movie has an important influence on increasing the intrinsic motivation of teacher candidates. It also indicates the education-themed movie has an important influence on decreasing extrinsic motivation-external regulation scores of teacher candidates, but has no influence on other sub-scales.

Table 10. T-test Results of ASTP Pre-Test and Post-Test Mean Scores of the Experiment Group

\begin{tabular}{lllclll}
\hline Sub-scales & & $\mathrm{n}$ & $\bar{X}$ & $S d$ & $t$ & $p$ \\
\hline \multirow{2}{*}{ Love } & Pre-test & 53 & 90.31 & 15.30 & \multirow{2}{*}{6.134} & $.000^{*}$ \\
& Post-test & 53 & 99.89 & 10.87 & & \\
\multirow{2}{*}{ Value } & Pre-test & 53 & 37.45 & 3.45 & -2.591 & $.012^{*}$ \\
& Post-test & 53 & 38.64 & 1.89 & & \\
\multirow{2}{*}{ Harmony } & Pre-test & 53 & 19.40 & 4.09 & -3.844 & $.000^{*}$ \\
& Post-test & 53 & 21.45 & 3.12 & & \\
\hline
\end{tabular}

The data in Table 10 show that ASTP love sub-scale post-test mean scores in the experiment group $(\bar{X}=99.89)$ are significantly higher than pre-test mean scores $(\bar{X}=90.31)(\mathrm{t}=-6.134, \mathrm{p}<.05)$. ASTP value sub-scale post-test mean scores in the experiment group $(\bar{X}=38.65)$ are significantly higher than pre-test mean scores $(\bar{X}=37.45)(\mathrm{t}=-2.591, \mathrm{p}<.05)$. ASTP harmony sub-scale post-test mean scores in the experiment group $(\bar{X}=21.45)$ are significantly higher than pre-test mean scores $(\bar{X}=19.40)(\mathrm{t}=-3.844, \mathrm{p}<.05)$. Based on those data, it can be seen that pre-test and post-test mean scores of experiment group increased significantly in all three sub-scales in favor of the post-test. This finding demonstrates that education-themed movie has an important effect on increasing the attitude of teacher candidates towards the profession of teaching.

\section{Discussion and Conclusion}

The findings of this study indicate that education-themed movie is effective on the intrinsic academic motivation and extrinsic academic motivation external regulation sub-scale scores of teacher candidates, but has no effect on other sub-scales. Based on this, it is concluded that education-themed movie leads to an increase in the intrinsic motivation scores of teacher candidates, while bringing on a decrease in the extrinsic motivation external regulation scores. Ayık and Ataş (2014), state that there is a positive and significant relation between the attitude of teacher candidates towards teaching profession and their motivation to teach, or between intrinsic motivation and extrinsic motivation, and that when the attitude towards the profession of teaching is positive, teaching motivation increases as well. However, it is remarkable to realize at the end of the study that extrinsic motivation-external regulation scores of teacher candidates significantly decrease, while their intrinsic motivation increases. İşcan (2011) emphasizes that movies are important tools in order to enhance student motivation during the processes of teaching-learning.

In the study of Fennell named "Movie and Teacher Training" (2013), it is pointed out that movies provide an opportunity to expose the teachers to real life conditions through gaining them in advance the information and experience about the situations they will face in their daily lives. In addition, it is emphasized that teacher candidates are given the chance to indirectly enter the world of teachers, students, school principals and families to have a similar environment to think over and discuss it. In a study conducted by Crume (1988), it is established that the teacher characters in movies play an important role in the lives of students and that teachers usually give a positive appearance rather than a negative one in movies and novels. Also for this study, it is possible to point that the fact that teacher candidates took the teacher character in the movie as an example contributed to improve their idea of the profession of teaching positively.

The results of this study show that education-themed movie had an important effect on in improving the teacher candidates' attitudes towards the profession of teaching. In a study carried out by Kaşkaya, Ünlü, Akar and Sağırlı 
(2011), it is concluded that movies change teacher candidates' attitudes towards their profession positively and increase their self-confidence. Birkök (2008) emphasizes that cinema can be specially constructed and conveniently used as a tool of movies, in line with the aims determined in a specific educational model, and thus it would be possible to effectively convey the knowledge of attitudes and behaviors and to establish behavioral models.

Tan (2006) points out that movies help contribute to reflective thinking in teacher candidates and guide them by attracting attention to different ideas. Moreover, Oruç and Sarıbudak (2015) found out in their study that educators watch a limited number of movies with educational content, they do not benefit from them sufficiently, while being positively affected by them. It is possible to say that academic motivation and attitudes towards the profession of teaching increase (Lin, 2002) with the help of cinema movies, as a means of media, which make learning more persistent (Kapucu, 2014). Besides, Rorrer and Furr (2009) underline that movies can be used as tools for approaching cultural awareness and influencing it. There are also some studies analyzing the effect of movies on the academic success in various subjects and learning process (Bektaş Öztaşkın, 2013; Champoux, 2007; Goldenberg, Lee \& O’Bannon, 2010; Kabaday1, 2012) and on development of thought and language (Çıkrıkç1, 1999).

On the basis of this study, it can be stated that employing teacher/education-themed movies in the training of teacher candidates can be considerably beneficial for creating positive effects on attitudes towards the profession of teaching. Movies can be utilized in promoting not only cognitive and psychomotor development, but also affective development during the preparatory process of teacher candidates. The different perspectives in the movies, as well as academic success, can be said to make significant contributions in pre-service training of teachers. In the same time, movies will create a more effective and productive teaching-learning process by means of providing rich experiences in learning environments in that they concretize abstract situations (Kuzma \& Haney, 2001).

\section{References}

Abbasoğlu, E. (2011). Beden eğitimi öğretmeni adaylarının öğretmenlik mesleğine iliş̧kin tutum ve benlik saygllarının incelenmesi (Yayımlanmamış yüksek lisans tezi). Karadeniz Teknik Üniversitesi Eğitim Bilimleri Enstitüsü, Trabzon.

Acat, M., \& Yenilmez, K. (2004). Eğitim fakültesi öğrencilerinin öğretmenlik mesleğine ilişkin motivasyon düzeyleri. Manas Sosyal Bilimler Dergisi, 12.

Ada, Ş., Akan, D., Ayık, A., Yıldırım, İ., \& Yalçın, S. (2013). Öğretmenlerin motivasyon etkenleri. Atatürk Üniversitesi Sosyal Bilimler Enstitüsü Dergisi, 17(3), 151-166.

Akbaba, S. (2006). Eğitimde motivasyon. Kazım Karabekir Eğitim Fakültesi Dergisi, 1(13), 343-361.

Akpan, I. D., \& Umobong, M. E. (2013). Analysis of achievement motivation and academic engagement of students in the Nigerian classroom. Academic Journal of Interdisciplinary Studies, 2(3). http://dx.doi.org/10.5901/ajis.2013.v2n3p385

Aktürk, A. O. (2012). Öğretmen adaylarının öğrenmeye ilişkin tutumlarının öğretmenlik mesleğini tercih etme nedenlerine ve akademik başarılarına göre incelenmesi. Ahi Evran Üniversitesi Kırşehir Eğitim Fakültesi Dergisi, 13(3), 283-297.

Altınkurt, Y., Yılmaz, K., \& Erol, E. (2014). Pedagojik formasyon programı öğrencilerinin öğretmenlik mesleğine yönelik motivasyonları. Trakya Üniversitesi Eğitim Fakültesi Dergisi, 4(1), 48-62.

Altıntaş, M. E. (2008). Din eğitimi açısından sihir ve büyü içerikli filmlerin etkilerine ilişkin çocukların algıları (Yayımlanmamış yüksek lisans tezi). Marmara Üniversitesi Sosyal Bilimler Enstitüsü, İstanbul.

Ames, C., \& Archer, J. (1988). Achievement goals in the classroom: Students' learning strategies and motivation processes. Journal of Educational Psychology, 80(3), 260-267. http://dx.doi.org/10.1037/0022-0663.80.3.260

Argon, T., İsmetoğlu, M., \& İşeri, B. (2014). İlkokullarda sanatsal denetim ve öğretmen motivasyonu üzerine öğretmen görüşleri. Ĕ̈itim ve Öğretim Araştırmaları Dergisi, 3(2), 286-296.

Ayık, A., \& Ataş, Ö. (2014). Öğretmen adaylarının öğretmenlik mesleğine yönelik tutumları ile öğretme motivasyonları arasındaki iliş̧i. Ë̆itim Bilimleri Araştırmaları Dergisi, 4(1), 25-43.

Barutçugil, İ. (2004). Stratejik insan kaynakları yönetimi (1 ed.). İstanbul: Kariyer Yayınc1lık.

Bek, Y. (2007). Öğretmenin toplumsal/mesleki rolleri ve statüsü (Yayımlanmamış bitirme projesi). Trakya Üniversitesi Sosyal Bilimler Enstitüsü, Edirne.

Bektaş Öztaşkın, Ö. (2013). Sosyal bilgiler derslerinde belgesel film kullanımının akademik başarıya ve bilinçli farkındalık düzeylerine etkisi. Eğitim Bilimleri Araştırmaları Dergisi, 3(2), 147-162. http://dx.doi.org/10.12973/jesr.2013.329a 
Birkök, M. C. (2008). Bir toplumsallaştırma aracı olarak eğitimde alternatif medya kullanımı: Sinema filmleri. Uluslararast Insan Bilimleri Dergisi, 5(2), 1-12. http://dx.doi.org/10.14687/ijhs.v5i2.574

Bozanoğlu, İ. (2004). Akademik güdülenme ölçeği: geliştirmesi, geçerliği, güvenirliği. Ankara Üniversitesi Eğitim Bilimleri Fakültesi Dergisi, 37(2), 83-98. http://dx.doi.org/10.1501/egifak_0000000094

Büyüköztürk, Ş. (2002). Sosyal bilimler için veri analizi el kitabı. Ankara: Pegema.

Çakıroğlu, E. \& Işıksal, M. (2009). İlköğretim öğretmen adaylarının matematiğe yönelik tutum ve özyeterlik algıları. Ĕgitim ve Bilim, 34(151), 132-139.

Can, G. (1987). Öğretmenlik meslek anlayışı üzerine bir araştırma. Anadolu Üniversitesi Eğitim Fakültesi Dergisi, 2(1), 159-170.

Cave, S. L. (2003). The effects of strengths education on the academic motivation of first-year college students. Azusa, California: Azusa Pacific University.

Çetin, Ş. (2006). Öğretmenlik mesleği tutum ölçeğinin geliştirilmesi (Geçerlik ve güvenirlik çalışması). Gazi Üniversitesi Endüstriyel Sanatlar Eğitim Fakültesi Dergisi, 18, 28-37.

Champoux, J. E. (2007). Film as a teaching resource. New Mexico: The University of New Mexico.

Çıkrıkçı, S. (1999). Çizgi filmlerin 5-6 yaş çocuklarının karam gelişimi ve kazanımına etkisi (Yayımlanmamış yüksek lisans tezi). Ankara Üniversitesi Sosyal Bilimler Enstitüsü, Ankara..

Crume, M. T. (1988). Images of teachers in novels and films for the adolescent, 1980-1987. Florida: University of Florida.

Dereli, E., \& Acat, M. B. (2010). Okul öncesi eğitim öğretmenliği bölümü öğrencilerinin motivasyon kaynakları ve sorunları. Selçuk Üniversitesi Sosyal Bilimler Enstitüsü Dergisi, 1(24), 173-187.

Dörnyei, Z. (2003). Attitudes, orientations, and motivations in language learning: Advances in theory, research, and applications. In Z. Dörnyei (Ed.), (pp. 3-32). Oxford: Blackwell.

Erdem, A. R., \& Gözel, E. (2014). Sınıf öğretmeni adaylarının öğretmenlik mesleğine ilişkin motivasyon düzeyleri. Akademik Sosyal Araştırmalar Dergisi, 2(1), 49-60.

Eymur, G., \& Geban, Ö. (2011). Kimya öğretmeni adaylarının motivasyon ve akademik başarıları arasındaki ilişkinin incelenmesi. Ĕgitim ve Bilim Dergisi, 36(161), 246-255.

Fennell, H. A. (2013). Reel stories of teaching: Film and teacher education. Action in Teacher Education, 35(5-6), 445-461. http://dx.doi.org/10.1080/01626620.2013.846762

Gardner, R. C. (1985). Social Psychology and second language learning: The role of attitudes and motivation. Maryland, USA: Edward Arnold (Publishers) Ltd.

Gök, S. (2009). Örgüt ikliminin çalışanların motivasyonuna etkisi üzerine bir araştırma. Uluslararası İnsan Bilimleri Dergisi, 6(2), 588-605.

Gökay, M., \& Özdemir, Ş. S. (2010). Görsel sanatlar (resim-iş) öğretmenlerinin motivasyonlarını etkileyen faktörler: Konya örneği. Dumlupinar Üniversitesi Sosyal Bilimler Dergisi, 26.

Goldenberg, M., Lee, J. W., \& O’Bannon, T. (2010). Enhancing recreation, parks and tourism courses: Using movies as teaching tools. Journal of Hospitality, Leisure, Sport and Tourism Education, 9(2), 4-16. http://dx.doi.org/10.3794/johlste.92.215

Gömleksiz, M. N., \& Serhatlığlu, B. (2013). Öğretmen adaylarının akademik motivasyon düzeylerine ilşkin görüşleri. Türkiye Sosyal Araştırmalar Dergisi, 3(17), 99-127.

Greene, B. A., Miller, R. B., Crowson, H. M., Duke, B. L., \& Akey, K. L. (2004). Predicting high school students' cognitive engagement and achievement: Contributions of classroom perceptions and motivation. Norman, USA. http://dx.doi.org/10.1016/j.cedpsych.2004.01.006

İlter, İ. (2013). Sosyal bilgiler öğretiminde $5 E$ öğrenme döngüsü modelinin öğrenci başarısına, bilimsel sorgulayıct-araştırma becerilerine, akademik motivasyona ve ögrenme sürecine etkileri (Yayımlanmamış doktora tezi). Atatürk Üniversitesi Eğitim Bilimleri Enstitüsü, Erzurum.

İman, E. D. (2014). Okul öncesi öğretmen adaylarının çocuk sevgisi ve öğretmenlik mesleğine ilişkin motivasyonlarının incelenmesi. Kuramsal Eğitimbilim Dergisi, 7(4), 482-505.

İşcan, A. (2011). Yabancı dil olarak Türkçe öğretiminde filmlerin yeri ve önemi. Turkish Studies - International Periodical For The Languages, Literature and History of Turkish or Turkic, 6(3), 939-948. 
Jonett, C. L. (2009). The motivation of teachers to assume the role of cooperating teacher. Doctoral Dissertations, ABD: Cardinal Stritch University.

Kabaday1, L. (2012). The role of short film in education. Procedia-Social and Behavioral Sciences, 47, 316-320. http://dx.doi.org/10.1016/j.sbspro.2012.06.657

Kaisershot, H. A. (2006). Academic motivation, coping indicators, receptivity to student support services and the first-year university experience. Grand Forks, North Dakota, USA: Graduate Faculty of the University of North Dakota.

Kapucu, M. S. (2014). Opinions of science teachers about the usage of visual media during science and technology course. Pegem Journal of Education \& Instruction, 4(2), 75-90.

Karagüven, M. H. Ü. (2012). Akademik motivasyon ölçeğinin Türkçeye adaptasyonu. Kuram ve Uygulamada Eğitim Bilimleri, 12(4), 2599-2620.

Karasar, N. (2005). Bilimsel araştırma yöntemi. Ankara: Nobel Yayın Dağıtım.

Karataş, H. (2011). Üniversite öğrencilerinin epistemolojik inançları, öğrenme yaklaşımları veproblme çözme becerilerinin akademik motivasyonu yordama gücü (Yayımlanmamış doktora tezi). Yıldız Teknik Üniversitesi Sosyal Bilimler Enstitüsü, İstanbul.

Kaşkaya, A., Ünlü, İ., Akar, M. S., \& Sağırlı, M. Ö. (2011). Okul ve öğretmen içerikli sinema filmlerinin öğretmen adaylarının mesleki tutumlarına ve öz yeterlik algılarına etkisi. Kuram ve Uygulamada Eğitim Bilimleri, 11(4), $1765-1783$

Küçükosmanoğlu, H. O. (2015). Müzik öğretmeni adaylarının akademik motivasyon düzeylerinin belirlenmesi üzerine bir çalı̧̧ma: Konya ili örneği. Sanat Eğitimi Dergisi, 3(1), 1-21.

Kuzma, L. M., \& Haney, P. J. (2001). And . . Action! Using film to learn about foreign policy. International Studies Perspectives, 2(1), 33-50. http://dx.doi.org/10.1111/1528-3577.00036

LeJeune, J. M. (2014). Exploring the relationship between teachers' motivation orientation and the efficacy of two professional development models. Reno, United States: University of Nevada.

Lin, L.Y. (2002). The effects of feature films upon learners' motivation, listening and speaking skills: The learner-centered approach. Taiwan: Learner Centered Instruction.

Linnenbrink, E. A., \& Pintrich, P. R. (2002). Motivation as an enabler for academic success. The School Psychology Review, 31(3), 313-327.

Montgomery, M. S. (1999). The development of the scale of academic motivation. Madison, USA: University of Wisconsin.

Nelson, L. (2011). Teachers' motivation to integrate technology: A study of expectancy-value, perceived instrumentality, and prosocial goals. Norman, Oklahoma, USA: University of Oklahoma.

Obuz, Y. (2011). Maddi ve maddi olmayan motivasyon unsurlarının cinsiyete dayalı ölçümü; perakendecilik sektöründe uygulaması (Yayımlanmamış bitirme projesi). Süleyman Demirel Üniversitesi Sosyal Bilimler Enstitüsü, Isparta.

Olsen, A. K. (2015). The effects of technology on academic motivation and achievement in a middle school mathematics classroom. United States: Master of Arts in the Graduate Program Caldwell University.

Oruç, Ş., \& Sarıbudak, D. (2015). Okul yöneticilerinin ve öğretmenlerin eğitim içerikli filmlerin eğitim ortamlarına etkisine ilişkin görüşleri. Internatıonal Journal of Field Educatıon, 1(1), 19-41.

Özgüngör, S., \& Kapıkıran, Ş. (2008). Güzel sanatlar eğitimi öğrencilerinin öğretmenlik meslek bilgisi derslerine ilişkin motivasyon ve başarı düzeyleri. Pamukkale Üniversitesi Eğitim Fakültesi Dergisi, 1(23), 47-60.

Özoğlu, M., Gür, B. S., \& Altunoğlu, A. (2013). Türkiye ve dünyada öğretmenlik. Retorik ve Pratik, 1(1), 41-60.

Pintrich,P. \& Schunk, D. (1996). Motivation in in education: theory, research and applications. Englewood Cliffs, NJ: Prentice-Hall.

Robertson, L. E. (2010). Autonomy and self-determination theory in different contexts: a comparison of middle school science teachers' motivation and instruction in China and the United States. Raleigh, North Carolina, USA.

Rorrer, A. S., \& Furr, S. (2009). Using film as a multicultural awareness tool in teacher education. Multicultural Perspectives, 11(3), 162-168. http://dx.doi.org/10.1080/15210960903116902

Ryan, R. M., \& Deci, E. L. (2000). Intrinsic and extrinsic motivations: Classic definitions and new directions. Contemporary Educational Psychology, 25, 54-67. http://dx.doi.org/10.1006/ceps.1999.1020 
Schunk, D. H., Pintrich, P. R., \& Meece, J. L. (2008). Motivation in education : theory, research, and applications (Vol. 3rd ed.). Upper Saddle River, N.J. : Pearson/Merrill Prentice Hall.

Settlemyer, J. B. (2010). Achievement motivation profiles of 2010 academic year graduates from Newberry College. South Carolina, USA: University of South Carolina College of Education.

Tan, C. (2006). Philosophical reflections from the silver screen: using films to promote reflection in pre - service teachers. Reflective Practice: International and, 7(4), 483-497. http://dx.doi.org/10.1080/14623940600987080

Uyulgan, M. A., \& Akkuzu, N. (2013). Öğretmen adaylarının akademik içsel motivasyonlarına. Kuram ve Uygulamada Eğitim Bilimleri Dergisi, 14(1), 7-32.

Vallerand, R. J., Pelletier, L. G., Blais, M. R, Brière, N. M., Sené- cal, C., \& Vallières, E. F. (1992). The academic motivation scale: a measure of intrinsic, extrinsic, and amotivation in education. Educational and Psychological Measurement, 52, 1003-1017. http://dx.doi.org/10.1177/0013164492052004025

Wagner, B. D. (2006). Motivation and professional growth In early childhood teachers. Rochester, New York: University of Rochester.

Walker, R. S. (1982). Effects of principal inservice training on teacher classroom behaviors and student academic motivation. Ames, Iowa: Iowa State University.

Wall, N. A. (2013). An investigation of middle school teachers'thinking about motivation. Greensboro, USA: the Faculty of the Graduate School at The University of North Carolina at Greensboro.

Weiner, B. (1990). History of motivational research in education. Journal of Educational Psychology, 82(4), 616-622. http://dx.doi.org/10.1037/0022-0663.82.4.616

Yavuz, C. \& Karadeniz, C. B. (2009). Sınıf öğretmenlerinin motivasyonunun iş tatmini üzerin etkisi. Uluslararası Sosyal Araştırmalar Dergisi, 2(9), 507-519.

Yılmaz, M., \& Aslan, Ö. (2013). Öğretmen motivasyonunun artırılmasında “Önkas” ödül sistemi. Uşak Üniversitesi Sosyal Bilimler Dergisi (Özel sayl), 286-306. http://dx.doi.org/10.12780/uusbd188

Zou, M. (2000). Comparative study of preservice teachers' academic motivation in a theoretical course, a practical course, and a liberal studies course. Pennsylvania, United States: Indiana University of Pennsylvania.

\section{(c) B $\mathrm{BY}$}

This work is licensed under a Creative Commons Attribution 3.0 License. 